\title{
The Effects of Forest Litter and Waterlogging on the Ecotoxicity of Soils Strongly Enriched in Arsenic in a Historical Mining Site
}

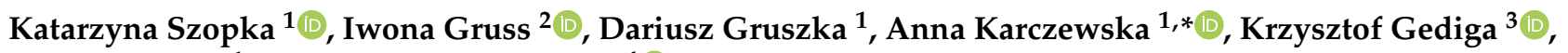 \\ Bernard Gałka $^{1}$ and Agnieszka Dradrach ${ }^{4}$ (I)
}

1 Institute of Soil Science and Environmental Protection, Wrocław University of Environmental and Life Sciences, 50-357 Wrocław, Poland; katarzyna.szopka@upwr.edu.pl (K.S.); 110260@student.upwr.edu.pl (D.G.); bernard.galka@upwr.edu.pl (B.G.)

2 Department of Plant Protection, Wrocław University of Environmental and Life Sciences, 50-363 Wrocław, Poland; iwona.gruss@upwr.edu.pl

3 Department of Plant Nutrition, Wrocław University of Environmental and Life Sciences, 50-357 Wrocław, Poland; krzysztof.gediga@upwr.edu.pl

4 Institute of Agroecology and Plant Production, Wrocław University of Environmental and Life Sciences, 50-363 Wrocław, Poland; agnieszka.dradrach@upwr.edu.pl

* Correspondence: anna.karczewska@upwr.edu.pl; Tel.: +48-713201940

check for updates

Citation: Szopka, K.; Gruss, I.; Gruszka, D.; Karczewska, A.; Gediga, K.; Gałka, B.; Dradrach, A. The Effects of Forest Litter and Waterlogging on the Ecotoxicity of Soils Strongly Enriched in Arsenic in a Historical Mining Site. Forests 2021, 12, 355. https://doi.org/10.3390/f12030355

Academic Editor: Tiina

Maileena Nieminen

Received: 16 February 2021

Accepted: 12 March 2021

Published: 17 March 2021

Publisher's Note: MDPI stays neutral with regard to jurisdictional claims in published maps and institutional affiliations.

Copyright: (c) 2021 by the authors. Licensee MDPI, Basel, Switzerland. This article is an open access article distributed under the terms and conditions of the Creative Commons Attribution (CC BY) license (https:/ / creativecommons.org/licenses/by/ $4.0 /)$.

\begin{abstract}
This study examined the effects of waterlogging and forest litter introduced to soil on chemical properties of soil pore water and ecotoxicity of soils highly enriched in As. These effects were examined in a 21-day incubation experiment. Tested soil samples were collected from Złoty Stok, a historical centre of arsenic and gold mining: from a forested part of the Orchid Dump $(19,600 \mathrm{mg} / \mathrm{kg}$ As) and from a less contaminated site situated in a neighboring forest $(2020 \mathrm{mg} / \mathrm{kg}$ As). An unpolluted soil was used as control. The concentrations of As, Fe and Mn in soil pore water were measured together with a redox potential Eh. A battery of ecotoxicological tests, including a bioassay with luminescence bacteria Vibrio fischeri (Microtox) and several tests on crustaceans (Rapidtox, Thamnotox and Ostracodtox tests), was used to assess soil ecotoxicity. The bioassays with crustaceans (T. platyurus, H. incongruens) were more sensitive than the bacterial test Microtox. The study confirmed that the input of forest litter into the soil may significantly increase the effects of toxicity. Waterlogged conditions facilitated a release of As into pore water, and the addition of forest litter accelerated this effect thus causing increased toxicity.
\end{abstract}

Keywords: mine dump; forest; beech litter; pore water; incubation; toxicity; microbiotests; Microtox; Rapidtox; Thamnotox; Ostracodtox

\section{Introduction}

Arsenic belongs to potentially toxic metalloids; therefore, soils highly contaminated with this element are the matter of considerable concern. There are several sites in the Sudetes mountain range (SW Poland) where arsenic ores were mined in the past. Among them, Złoty Stok (German: Reichenstein) was one of the main European gold and arsenic mining centers. Numerous mine dumps and slag heaps remained there spread in a forested area. Waste material disposed on the dumps as well as soils in surrounding forests contain very high concentrations of As [1,2]. The processes of rock weathering lead to a slow release of As into soils and water $[3,4]$ thus causing a considerable environmental risk. In spite of the fact that As usually remains poorly soluble in soils due to its strong binding by iron, aluminum, and manganese oxides [5,6], its solubility can increase considerably under certain conditions. The release of arsenic from soil solid phase may be caused by strongly acidic or alkaline $\mathrm{pH}$, low redox potential or the presence of substances, such as phosphates or organic compounds, that compete with arsenates for the sorption sites on oxides [5,7-11]. 
Such conditions, i.e., the input of organic matter and periodic anaerobiosis, may occur in soils formed on forested mine dumps strongly enriched in arsenic, and in the soils in adjacent forests. Land surface in those sites has a relatively rich microrelief which means that in certain periods, after longer rainfall or spring snow thaw, waterlogging conditions may form in local depressions, lasting for several weeks and leading to a significant decrease in the redox potential. The presence of decaying forest litter should be considered as an additional factor that can cause deepening of anaerobiosis [10,12].

The processes of As mobilization in such conditions have been the subject of many studies, however the effects that the increased solubility of toxic As may cause in soil biocenosis have been poorly understood. Such knowledge would be essential to assess the ecological risk in those areas.

Reductive dissolution of amorphous and crystalline iron hydroxides, the main hosting phases for As in soils, may lead to intensive As release under reducing conditions. Those processes are often mediated by microbial activity [13-15]. Changing redox conditions usually affect the speciation of As in pore water, influencing its affinity to sorption sites that is much lower in the case of arsenites As(III) compared to arsenates As(V) [5,15-17]. Soil microbiota, as well as several components of soil pore water can, however, cause also a subsequent oxidation of As(III) [14,18], which makes the effects of reducing conditions on the solubility of As in soils difficult to predict.

The presence of dissolved or particulate organic matter makes those processes even more complex. Numerous researchers reported a release of As from organic matteramended soils due to the competition for sorption sites on iron hydroxides $[7,9,10,19-22]$. Several other mechanisms, such as redox reactions, complexation, and colloid formation can also be involved in the processes of As mobilization and resorption in soils in the presence of organic matter [7,22-24]. For instance, the forest litter-derived compounds can further bind arsenates leading to their sorption on soil solid phase, thus contributing to As removal from soil solution. The products derived from decomposition of plant residues under oxidized and anoxic conditions differ in their properties [25-27], which additionally influences the fate of As in the soil system.

The reaction of biota to the presence of As in soil depends on its release into the pore water, and additionally on its speciation in the solution and the presence of other components that can act synergistically or antagonistically. Moreover, the bioavailability of As for some soil organisms, such as earthworms, depends not only on the current but also on potential solubility. The ecotoxic effects of As in highly enriched soils are therefore very difficult to predict based on chemical properties of soil and soil pore water. The response of various groups of organisms to hazardous substances can be highly site-specific, therefore the batteries of tests, using a wide range of organisms, should be performed together with chemical analyses, in order to obtain the comprehensive assessment of ecological risk [28-30].

Various toxicological tests have been developed up to now and accepted by OECD or/and ISO as standard procedures [28-32]. Particular attention has been given to commercially available microbiotests, such as the Toxkit tests, which are easy in maintenance, ecologically relevant, sensitive to a broad range of toxicants and standardizable [33]. The sets of Toxkit tests contain all materials and the test organisms, necessary to perform the simple, rapid, sensitive and highly reproducible toxicity tests in aquatic and terrestrial environments.

The aim of research presented in this study was to assess the effects of waterlogging and the input of forest litter into the soil on the solubility and ecotoxicity of As measured with a battery of ecotoxicological tests, including a bioassay with bacteria (Microtox) and several tests on crustaceans (Rapidtox, Thamnotox and Ostracodtox toxkits). These tests involved the assessment of both acute and subchronic toxicity posed to biota by soil pore water and total soil samples. They have proved effective in studying environmental contamination with metals and metalloids $[30,31,34,35]$. The study covered the soil collected 
from the forested part of the Orchid Dump [12], highly enriched in As, and much less contaminated soil from a neighboring forest.

\section{Materials and Methods}

\subsection{Soils}

Two large (ca. $40 \mathrm{~kg}$ ) samples of soils, representative for the mineral soil layer 0-20 cm, were collected from two sites in Złoty Stok: S1-a forested part of the Orchid dump [12] and S2-a nearby mixed-species forest stand (Figure 1). Beech (Fagus sylvatica L.) associated by spruce (Picea abies L.) and maple (Acer pseudoplatanus L.) were the dominant tree species in those sites. The representativeness of samples for the approximately $50 \mathrm{~m}^{2}$ large areas was ensured in each case by mixing 16 sub-samples taken based on regular grids. Additionally, a sample of control soil (C) was collected from an unpolluted area, situated outside of the area of Złoty Stok.

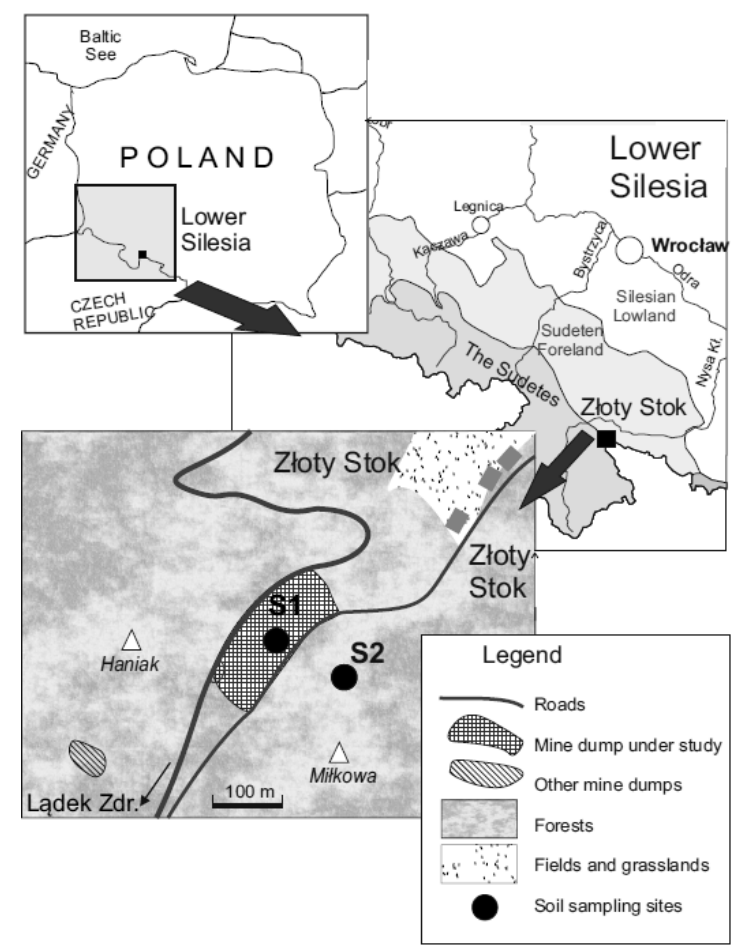

Figure 1. Location of Złoty Stok in Poland and situation of soil sampling sites.

Soil material was sieved to $<5 \mathrm{~mm}$ on site, brought to laboratory, air-dried, crushed and homogenized prior to the experiment. Aliquots of the fine earth fraction $(<2 \mathrm{~mm})$ were analyzed in triplicates for basic properties (Table 1) using the standard methods [36]. Dissolved organic carbon (DOC) was extracted in cold water, according to Gregorich et al. [37] and determined by a TOC 5000 Shimadzu analyzer. Soil $\mathrm{pH}$ was measured potentiometrically in a suspension with $1 \mathrm{M} \mathrm{KCl}, 1: 2.5(v: v)$. Total As was determined by ICP-AES (Thermo Scientific, iCAP 7400, Waltham, MA, USA), after microwave-assisted digestion with aqua regia [38]. The accuracy of analytical methods was checked with certified reference materials, CNS392 and CRM044, supplied by Sigma-Aldrich. Easily soluble As in soils was determined by ICP-AES after extraction with $1 \mathrm{M} \mathrm{NH}_{4} \mathrm{NO}_{3}$ [39]. 
Table 1. Basic properties of soils and forest litter (mean values of 3 replicates).

\begin{tabular}{cccccc}
\hline Parameter & Unit & $\begin{array}{c}\text { Control } \\
\text { C }\end{array}$ & $\begin{array}{c}\text { Dump Soil } \\
\text { S1 }\end{array}$ & $\begin{array}{c}\text { Forest Soil } \\
\text { S2 }\end{array}$ & $\begin{array}{c}\text { Forest Litter } \\
\text { FL }\end{array}$ \\
\hline Skeleton (fine gravel, $2-5 \mathrm{~mm})$ & $\%$ & 8 & 60 & 20 & $\mathrm{n} / \mathrm{a}$ \\
\hline $0.05-2.0 \mathrm{~mm}$ & $\%$ & 52 & 83 & 55 & \\
$0.002-0.5 \mathrm{~mm}$ & $\%$ & 42 & 14 & 44 & $\mathrm{n} / \mathrm{a}$ \\
$<0.002 \mathrm{~mm}$ & $\%$ & 6 & 3 & 1 & \\
\hline Textural group (USDA) & - & Sandy loam & Loamy sand & Sandy loam & $\mathrm{n} / \mathrm{a}$ \\
\hline Corg & $\mathrm{g} / \mathrm{kg}$ & 16.8 & 1.3 & 34.2 & 510 \\
DOC (cold water) & $\mathrm{g} / \mathrm{kg}$ & 0.1 & $<0.1$ & 0.5 & 4.1 \\
$\mathrm{~N}$ total & $\mathrm{g} / \mathrm{kg}$ & 1.4 & 0.3 & 2.6 & 21.5 \\
\hline $\mathrm{pH}$ & - & 6.1 & 5.5 & 4.0 & 5.2 \\
CEC & $\mathrm{cmol}(+) / \mathrm{kg}$ & 27.3 & 14.4 & 16.6 & $\mathrm{n} / \mathrm{a}$ \\
As total & $\mathrm{mg} / \mathrm{kg}$ & 3.6 & 19600 & 2020 & 2.7 \\
\hline M NH $\mathrm{NO}_{3}$-extractable As & $\mathrm{mg} / \mathrm{kg}$ & $<0.05$ & 3.61 & 1.91 & $<0.05$ \\
\hline n/a-not applicable. & & & & &
\end{tabular}

\subsection{Forest Litter}

Beech forest litter (FL) used in the experiment was collected in an early spring (March 2020) from a 60-year-old beech woodland. It represented a typical ca. $15 \mathrm{~cm}$-thick mull that contained partly decomposed beech foliage. The beech litter was air-dried, crumbled, and sieved to $1 \mathrm{~cm}$. Its analysis was performed with same methods as soil analysis, except for texture that obviously was not determined, and $\mathrm{pH}$ which was measured in water suspension $(1: 2.5 v: v)$.

\subsection{Incubation Experiment}

Soils were incubated in 1-kg pots for 21 days at two various moisture conditions: oxidized (Ox), i.e., at $70 \%$ of water holding capacity, and waterlogged, assumptionally anoxic (An), i.e., at $100 \%$ of maximum water capacity. The experiment, carried out in triplicates, involved the treatments with the addition of forest litter (FL), mixed with soil at the rate $20 \mathrm{~g} / \mathrm{kg}$ on dry matter basis, and those without forest litter (0). Soil pore water was collected with MacroRhizon suction samplers as described previously [10-12]. The samples of soil and soil pore water were collected twice, after 7 and 21 days of incubation, analyzed on their chemical properties and subjected to the battery of ecotoxicological bioassays.

\subsection{Chemical Analysis of Pore Water}

The analysis of pore water $\mathrm{pH}$ and redox potential was performed immediately after sampling, using potentiometric methods. The values of $\mathrm{pH}$ were measured with standard glass electrode, while redox potential Eh was determined with a platinum electrode InLab redox Micro (Mettler Toledo). Pore water aliquots for analysis of potentially toxic elements (As, Fe and $\mathrm{Mn}$ ) were stabilized by adding a drop of concentrated $\mathrm{HNO}_{3}$. The concentrations of those elements in pore water samples were determined by ICP-AES (Thermo Scientific, iCAP 7400, Waltham, MA, USA).

\subsection{Bioassays}

The aliquots of pore water for bioassays were placed in completely filled and tightly closed $30 \mathrm{~mL}$ test tubes, without air access, and immediately used for microbiotests: Microtox, Rapidtox and Thamnotox. Small aliquots of soil samples (ca. $50 \mathrm{~g}$ ) were taken from the pots and subject the Ostracodtox bioassay with two different parameters: growth and mortality measured as the endpoints. All the Toxkit materials and test organisms were purchased from Tigret (Warszawa, Poland). The tests were performed strictly following their operational procedures. 


\subsubsection{Microtox $^{\circledR}$}

The Microtox ${ }^{\circledR}$ acute toxicity test [40] is based on the inhibition of bioluminescence of bacteria Vibrio fischeri, presently classified as Allivibrio fischeri [41-43], in contaminated aqueous samples. The toxicity of soil pore water to bacteria was determined in a screening mode, using the $81.9 \%$ basic test protocol. Readings of bioluminescence were made in triplicates after $5^{\prime}$ and $15^{\prime}$ exposure of bacteria to soil pore water, using a Microtox ${ }^{\circledR}$ Model 500 analyzer (Strategic Diagnostics Incorporated SDIX, formerly Microbics Corporation, Newark, DE, USA). The entire procedure followed the 1992 Microtox ${ }^{\circledR}$ Manual [44]. The toxicity was expressed as percent effect (\%).

\subsubsection{Rapidtox}

The Rapidtoxkit (MicroBioTests Inc., Mariakerke, Gent, Belgium) is a rapid, 30-60 min sublethal assay based on the measurement of reduction in ingestion of red microspheres by the test organisms which are the larvae of the freshwater crustacean, a fairy shrimp Thamnocephalus platyurus $[45,46]$. Briefly, the cysts of T. platyurus were hatched under standardized conditions $\left(24 \mathrm{~h}, 25^{\circ} \mathrm{C}\right.$, continuous illumination) and exposed to contaminated water for $1 \mathrm{~h}$ in dark $\left(25^{\circ} \mathrm{C}\right)$. Standard Freshwater was used as control. Then, a suspension of red microspheres was added to test tubes and T. platyurus larvae were allowed to feed on these spheres for $15 \mathrm{~min}$. The endpoint of this test was the reduction in ingestion of microspheres, as compared to the control, expressed in \%. All the measurements were made in triplicate.

\subsubsection{Thamnotoxkit $\mathrm{F}^{\mathrm{TM}}$}

The acute toxicity Thamnotoxkit test measures the mortality of the same freshwater shrimp Thamnocephalus platyurus exposed to the samples of contaminated water [47,48], according to ISO 14380:2011 [49]. The test is a $24 \mathrm{~h}$ bioassay, performed in a multiwell test plate. The larvae of the shrimp were hatched from cysts $24 \mathrm{~h}$ prior to the start of the test. Then, they were exposed to contaminated pore water and incubated at $25^{\circ} \mathrm{C}$ for $24 \mathrm{~h}$ in the dark. The number of dead larvae was recorded after that time, and the test endpoint was mortality expressed in percent (\%). The test was performed in triplicate.

\subsubsection{Ostracodtoxkit $\mathrm{F}^{\mathrm{TM}}$}

The Ostracodtoxkit FTM bioassay is a 6 day "direct contact" toxicity test originally developed to measure the toxicity of freshwater sediments, adopted also for contaminated soils [47,50-52]. The test uses neonates of the benthic ostracod crustacean Heterocypris incongruens. The test is performed in multiwell plates in which the test organisms are hatched from cysts and exposed for 6 days to a thin layer of soil, covered by the Standard Freshwater. Two different effects, expressed in percent, are determined at the end of the exposure: the inhibition of growth and the mortality. The results are compared to those obtained in a parallel test with a non-toxic sample of a reference sediment.

\subsection{Statistics}

The results of this experiment did not show a normal distribution, and could not be normalized by common methods, therefore they were statistically analyzed by nonparametric statistics. The differences among the treatments (Ox vs. An, and 0 vs. FL) were analyzed by a two-sample Kolmogorov-Smirnov test. The main parameters (median values, $25-75 \%$ percentiles and the ranges) of the pairs of variables were additionally illustrated in the graphs.

Non-parametric Spearman rank correlation coefficients were calculated to examine the relationships between the chemical parameters of pore water and the results of bioassays. Principal component analysis (PCA) was performed to illustrate the distribution patterns of experimental data at reduced number of variables. A 2-D plot displaying the relationships between components was produced in order to illustrate the relationships between chemical and ecotoxicological data. Only those components were considered that contributed to a 
total variance to at least $10 \%$. All the statistical analyses were performed using a software Statistica, version 13.0 (Dell Inc., Round Rock, TX, USA).

\section{Results}

\subsection{Properties of Soils and Forest Litter}

Soils differed considerably in their properties (Table 1). The soil S1 contained high amounts of skeleton (that partly was removed in the field), and the share of a fine gravel fraction $(2-5 \mathrm{~mm})$, determined in the laboratory, was as high as $60 \%$. It's fine earth fraction had a texture of loamy sand. This soil was poor in organic matter (C org. $1.3 \mathrm{~g} / \mathrm{kg}$ ), had a slightly acidic $\mathrm{pH}$ and contained extremely high concentration of $\mathrm{As}(19,600 \mathrm{mg} / \mathrm{kg})$. Soils C and S2 had the textures of sandy loams and contained higher amounts of organic matter. Soil S2 was more acidic in reaction compared to S1 (pH 4.0) and contained lower concentration of As: $2020 \mathrm{mg} / \mathrm{kg}$. The concentration of As in the control soil C was typical for unpolluted sites $(3.6 \mathrm{mg} / \mathrm{kg}$ ).

The forest litter had slightly acidic $\mathrm{pH} 5.2$ and contained relatively low amounts of DOC $(4.1 \mathrm{~g} / \mathrm{kg}$, i.e., $0.8 \%$ of total C).

\subsection{Chemistry of Soil Pore Water}

The main parameters that characterize chemical composition of soil pore water, i.e., the concentrations of As, Mn and Fe, as well as the values of redox potential Eh are presented in Figure 2. The columns present mean values and error bars stand for confidence intervals at $p=0.95$.
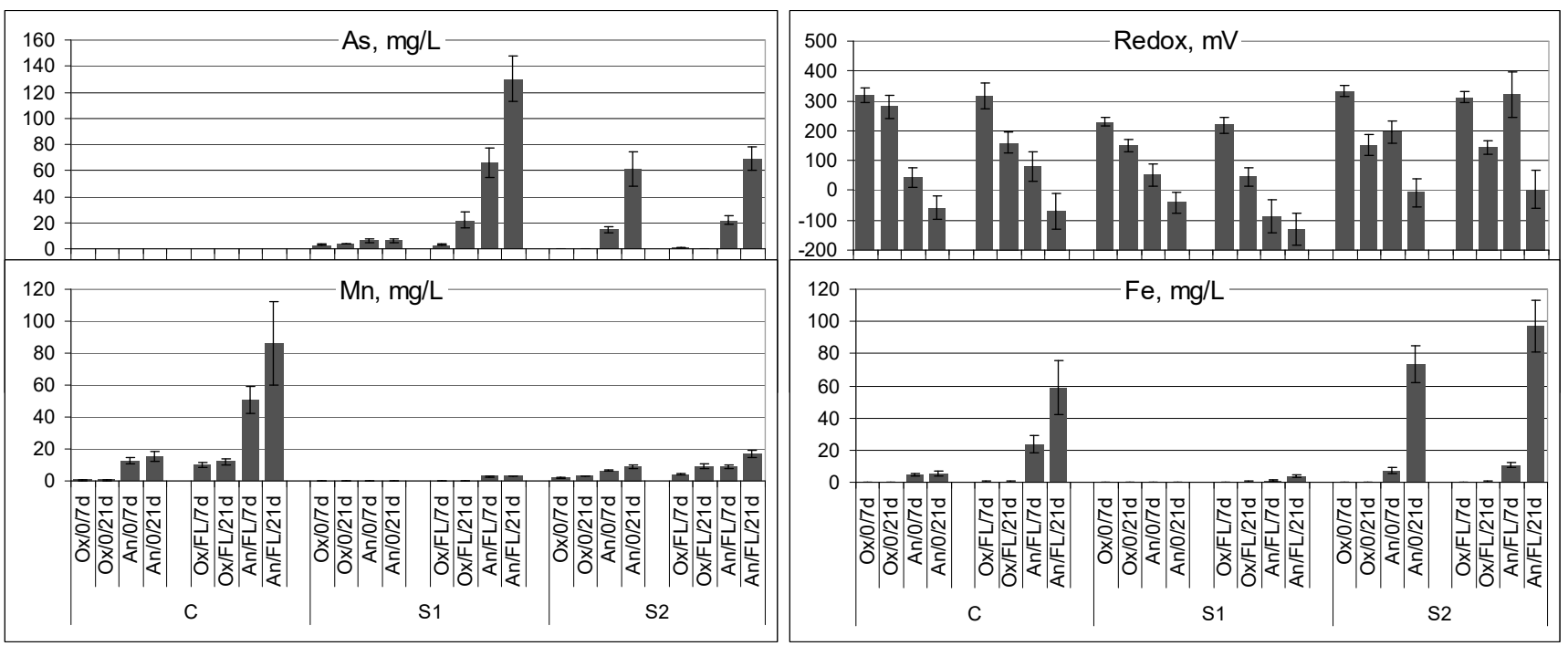

Figure 2. Chemical parameters that characterize soil pore water collected after incubation of variously treated soils C, S1 and S2. Error bars stand for standard deviation. Abbreviations: Ox-oxidized conditions of incubation (moisture: 70\% of field water capacity), An-anoxic conditions of incubation (waterlogged soils: $100 \%$ of total water capacity); 0-soils without addition, FL—soils treated with forest litter; time of incubation: 7 days (7d) or 21 days (21d).

In the case of S1, the addition of forest litter (FL) caused an apparent increase in As concentrations in soil solutions compared to the treatments without that addition(0), while in the case of S2, such an effect was not observed. Extremely high concentrations of As in soil solutions, exceeding $50 \mathrm{mg} / \mathrm{L}$, and reaching $135 \mathrm{mg} / \mathrm{L}$ in soil S1, were recorded after a longer incubation time, i.e., 21 days, in the treatments with forest litter (FL) and under waterlogged conditions. It can partly be explained by the effect of As (V) reduction to As (III), as the affinity of arsenites (As (III)) for iron hydroxide sites is much lower than that of arsenates $(\mathrm{As}(\mathrm{V}))[16,17]$. The prolonged incubation of soils under waterlogging conditions $(\mathrm{An})$, especially in the treatments with forest litter (FL), resulted in a statistically significant decrease in redox potential. This was accompanied by the release of $\mathrm{Mn}$ and $\mathrm{Fe}$, especially 
in soils C and S2, while in S1 this effect was relatively small. Reductive dissolution of Mn and Fe oxides apparently caused in the case of soil S2, a further, considerable release of As from solid phase in spite of its much lower total concentration compared to soil S1.

\subsection{Bioasssays}

The response of test organisms examined in bioassays to soil treatment with forest litter and to different moisture conditions is shown in Figure 3. Surprisingly, in unpolluted control soil (C) incubated at 70\% of soil moisture, i.e., under oxic conditions (Ox) without the addition of forest litter (0), non-zero toxic reactions were observed in the case of the Microtox test. The Rapidtox test performed on the soil $\mathrm{C}$ yielded highly diverse results with the non-zero means which were, however, not statistically significantly different from zero. The toxicity measured in all the treatments in two soils contaminated with As (S1, S2) was apparently much higher than that in the control soil (C) and it often reached $100 \%$, in particular in waterlogged soils treated with forest litter. This effect was observed in all the bioassays with crustacean, i.e., both in the acute toxicity tests Rapidtox and Thamnotox, and in the sub-acute Ostracodtox tests.
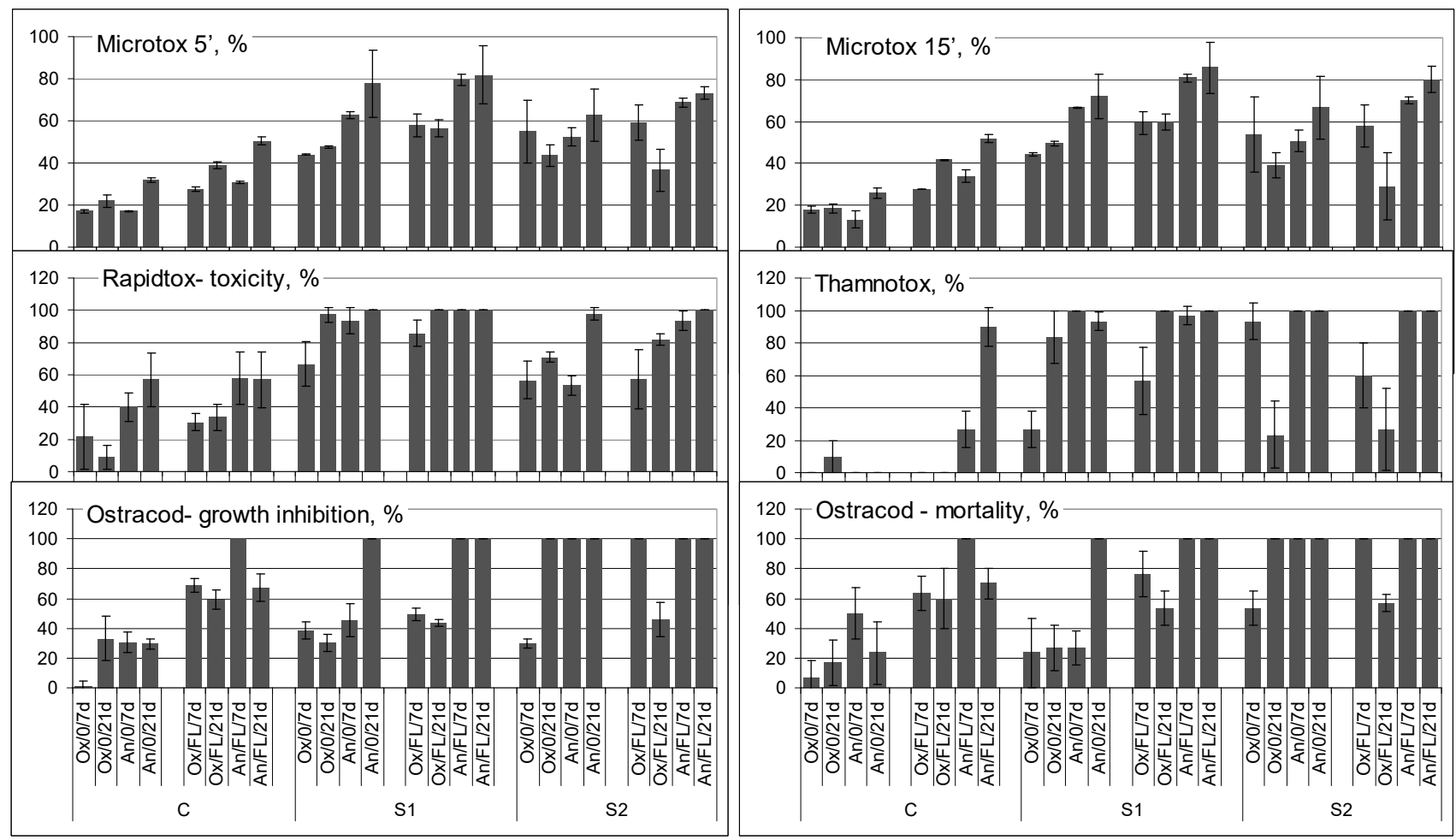

Figure 3. The results of bioassays performed on pore water and soils. Error bars stand for standard deviation. Abbreviations: see Figure 2.

\section{Discussion}

The experiments confirmed a higher sensitivity of the tests with crustaceans in comparison to Microtox bacterial tests based on the luminescence of Vibrio fischeri [53].

It should be stressed that the toxicity in all these tests was undoubtedly caused not only by the presence of As in soil or soil pore water, but also by other factors, as evidenced by the results for the control soil. In the Rapidtox and Thamnotox tests in the control soil, clear toxicity effects were revealed under waterlogging conditions, which can be explained by the release of toxic Fe and $\mathrm{Mn}$, as well as quite likely by an oxygen deficiency under these conditions. Rather unexpectedly, in the Ostracod tests, the toxicity effect at the level over $50 \%$ occurred in the treatments of control soil (C) with the addition of forest litter, 
regardless of the moisture conditions and the incubation time (Figure 3). This referred to both parameters measured in the Ostracodtox tests, i.e., growth and mortality.

The presence of $\mathrm{Fe}$ at various oxidation states, as well as the products of organic matter transformation in soil pore water, make the interpretation of $\mathrm{As}(\mathrm{III})$ and $\mathrm{As}(\mathrm{V})$ behavior and toxicity in the soil system quite complex [54]. Reduced forms of As (III) are known to be much more toxic compared to As (V) [5,14]. Unfortunately, As speciation in pore water was not examined in this study. On the other hand, however, at neutral or alkaline $\mathrm{pH}$, the radicals produced by transformation of organic matter can act as oxidants and oxidize arsenite to arsenate, thus decreasing As toxicity and mobility [54]. In order to statistically examine the effects of waterlogging and the presence of forest litter on the toxicity of soils, the experimental results were subjected to statistical analysis using non-parametric methods. Figure 4 illustrates the comparison of treatments differing in moisture conditions during incubation (Ox vs. An). The medians (i.e., the main indicators in non-parametric analysis), of both As concentrations in pore water and the results of all ecotoxicological tests were higher in the waterlogged conditions (An) compared to $70 \%$ soil moisture. The ranges of the second and third quartiles (25-75\%) were also clearly different between those two sets of results (Figure 4).
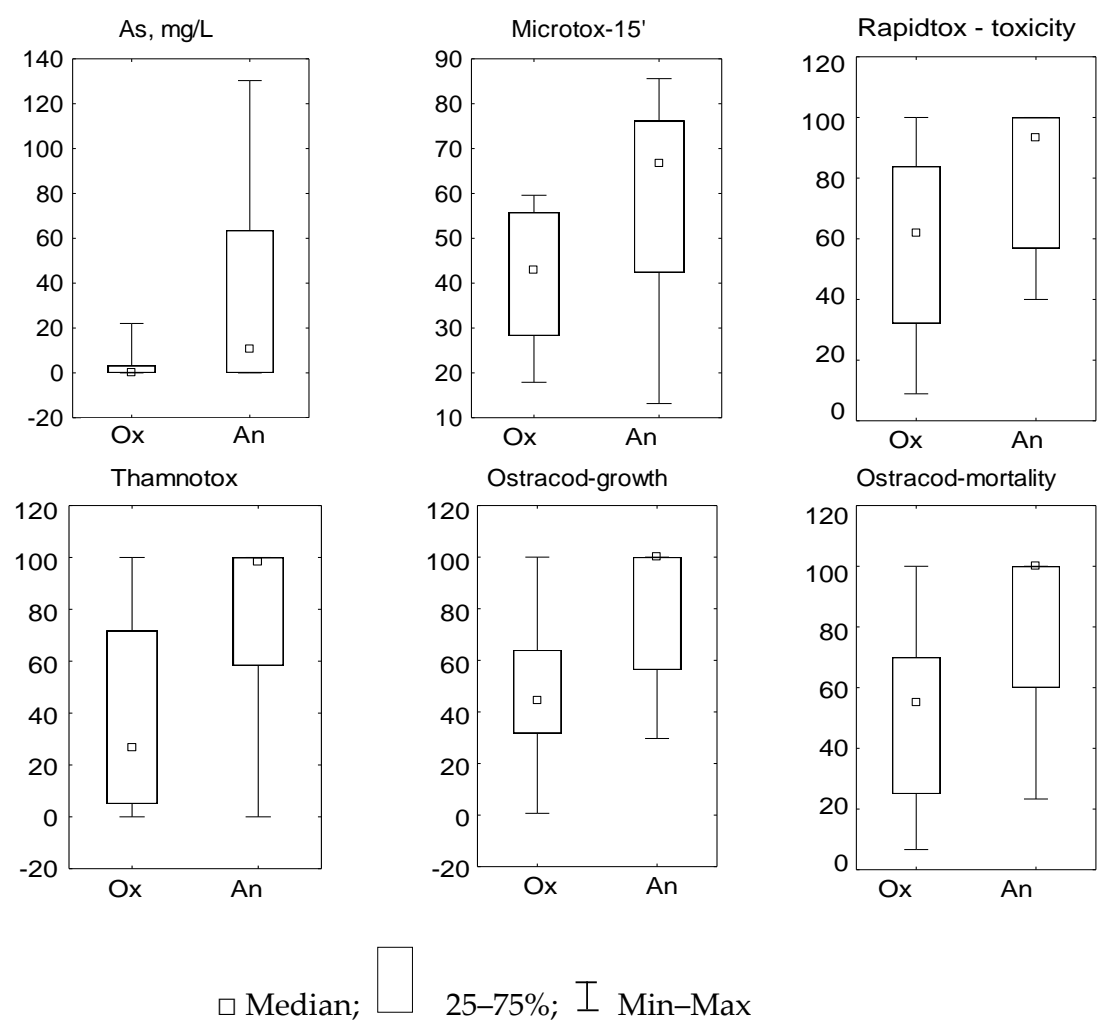

25-75\%; I Min-Max

Figure 4. The comparison of treatments differing in moisture conditions during incubation (Ox vs. An).

Similarly, the comparison of the medians for the variants with and without forest litter (Figure 5) clearly illustrate that the input of forest litter to soils resulted in generally higher ecotoxicity determined throughout the experiment. The results of a non-parametric Kolmogorov-Smirnov test (Table 2) confirm that the addition of FL significantly affected the results of the Ostracod tests throughout the experiment (at $p<0.05$ for and at $p<0.01$ for mortality as the endpoints). Waterlogging proved to have a statistically significant effect on As concentrations in soil pore water and on the results of Microtox and Thamnotox tests. 

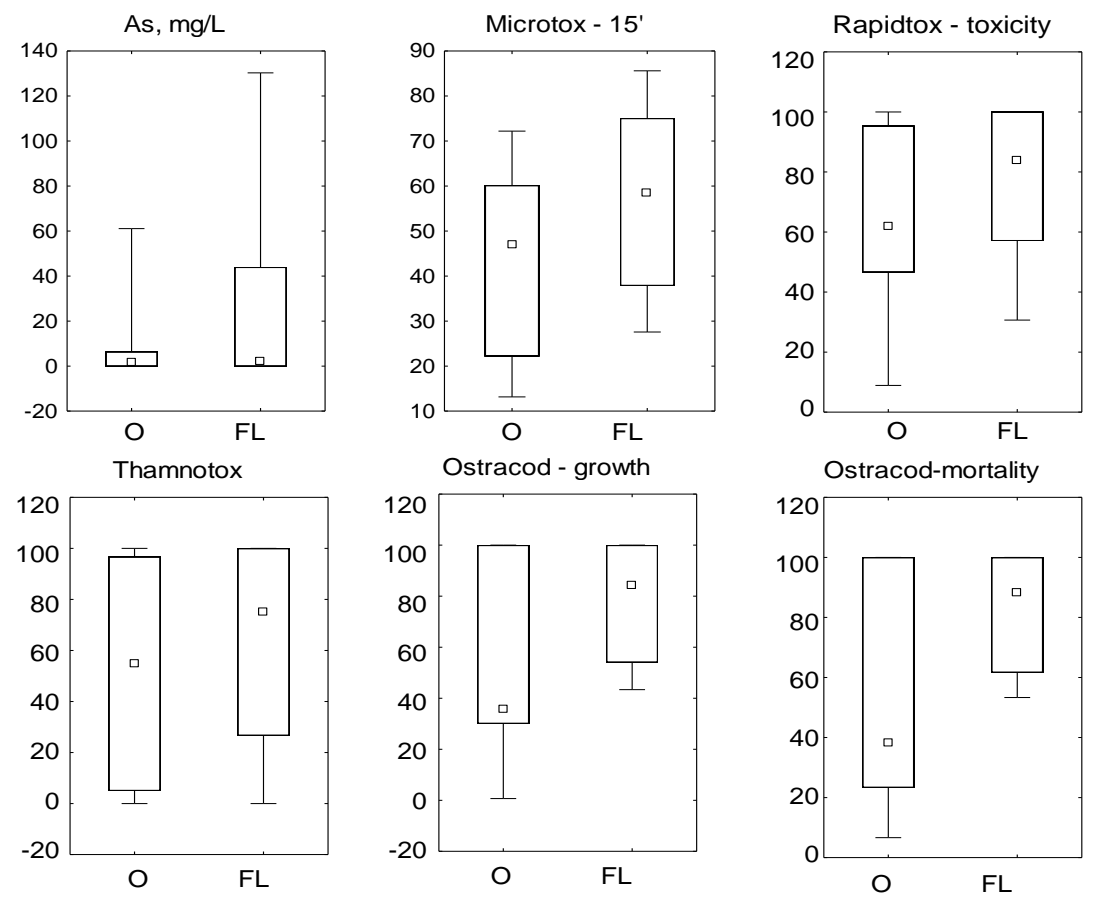

\section{$\checkmark$ Median; $\square$ 25-75\%; I Min-Max}

Figure 5. The comparison of treatments with and without addition of forest litter ( 0 vs. FL).

Table 2. The results of two-sample Kolmogorov-Smirnov test for differences between the pairs of variables.

\begin{tabular}{|c|c|c|c|c|c|c|c|c|c|c|}
\hline \multirow[b]{2}{*}{ Parameter } & \multicolumn{5}{|c|}{ Tested Pairs of Variables: Ox/Anox } & \multicolumn{5}{|c|}{ Tested Pairs of Variables: 0/FL } \\
\hline & $\begin{array}{c}\text { Mean } \\
\text { Ox }\end{array}$ & $\begin{array}{l}\text { SD } \\
\text { Ox }\end{array}$ & $\begin{array}{l}\text { Mean } \\
\text { Anox }\end{array}$ & $\begin{array}{c}\text { SD } \\
\text { Anox }\end{array}$ & $p$ & $\begin{array}{c}\text { Mean } \\
0\end{array}$ & $\begin{array}{c}\text { SD } \\
0\end{array}$ & $\begin{array}{c}\text { Mean } \\
\text { FL }\end{array}$ & $\begin{array}{c}\text { SD } \\
\text { FL }\end{array}$ & $p$ \\
\hline As, mg/L & $2.8 *$ & 6.2 & $31.3 *$ & 41.4 & $p<0.05$ & 8.0 & 17.3 & 26.1 & 41.4 & \\
\hline Microtox-5 $5^{\prime}, \%$ & $41.5^{*}$ & 14.0 & 57.4 * & 21.3 & $p<0.05$ & 43.5 & 18.9 & 56.4 & 20.3 & \\
\hline Microtox-15', \% & $42.3 *$ & 12.4 & $58.1 *$ & 23.3 & $p<0.05$ & 45.5 & 17.9 & 56.8 & 17.4 & \\
\hline Rapidtox, $\%$ & 59.2 & 30.1 & 79.1 & 23.6 & & 63.6 & 30.3 & 74.8 & 26.3 & \\
\hline Thamnotox, \% & $40.0 *$ & 37.3 & $75.6 *$ & 40.9 & $p<0.05$ & 52.5 & 45.4 & 63.1 & 40.4 & \\
\hline Ostracod-growth, \% & 49.9 & 28.8 & 81.1 & 29.4 & & $53.2 *$ & 30.1 & $77.8 *$ & 24.4 & $p<0.05$ \\
\hline Ostracod-mortality, \% & 53.0 & 30.4 & 80.8 & 30.5 & & $52.2 * *$ & 37.5 & $81.7 * *$ & 20.0 & $p<0.01$ \\
\hline
\end{tabular}

$*, * *$ Asterisks indicate the means that differ significantly at $p<0.05$ and $p<0.01$.

Mobilization of As into soil water under anoxic conditions is a well known phenomenon described by numerous authors [11,13-16,55], though the removal of As from pore water after a long term waterlogging was reported as well $[11,14,56]$, and explained for instance by subsequent biological oxidation of As (III) [14,18], its sorption by newly formed FeS [56] or binding by sulfur groups [57].

The results of all the tests based on soil pore water reflected well the concentrations of As. The relationships between the chemical parameters of pore water $(\mathrm{pH}$, redox potential Eh and As, Mn and Fe concentrations) and the results of biotests-examined in pairs in a non-parametric Spearman rank correlation test-confirmed strong relationships between As in pore water and the results of Microtox, Rapidtox and Thamnotox tests (Table 3). The relationship between pore water As and the results of Ostracod tests were weaker, as shown by lower correlation coefficients and lower significance. These relationships are also well seen in the PCA graph (Figure 6). 
Table 3. Significant Spearman correlation coefficients between soil pore water parameters and the results of bioassays.

\begin{tabular}{|c|c|c|c|c|c|c|c|c|c|}
\hline & $\begin{array}{c}\mathrm{Mn} \\
\mathrm{mg} / \mathrm{L}\end{array}$ & $\begin{array}{c}\mathrm{Fe} \\
\mathrm{mg} / \mathrm{L}\end{array}$ & Redox & $\begin{array}{c}\text { Microtox } \\
5^{\prime}\end{array}$ & $\begin{array}{c}\text { Microtox } \\
15^{\prime}\end{array}$ & Thamnotox & Rapidotox & $\begin{array}{l}\text { Ostracod- } \\
\text { Growth }\end{array}$ & $\begin{array}{l}\text { Ostracod- } \\
\text { Mortality }\end{array}$ \\
\hline Incubation time & - & - & $-0.506^{*}$ & - & - & - & - & - & - \\
\hline $\mathrm{pH}$ & - & - & - & - & - & - & - & $-0.489 *$ & $-0.598^{* *}$ \\
\hline As, $\mathrm{mg} / \mathrm{L}$ & - & - & - & $0.827 * * *$ & $0.873^{* * *}$ & $0.883^{* * *}$ & $0.847^{* * *}$ & $0.484 *$ & $0.502 * *$ \\
\hline $\mathrm{Mn}, \mathrm{mg} / \mathrm{L}$ & $\mathrm{x}$ & $0.821^{* * *}$ & - & - & - & - & - & - & - \\
\hline $\mathrm{Fe}, \mathrm{mg} / \mathrm{L}$ & & $\mathrm{x}$ & -0.431 * & - & _ & _ & - & $0.452 *$ & 0.464 * \\
\hline Redox & & & $x$ & - & - & - & $-0.557^{* *}$ & - & - \\
\hline Microtox-5' & & & & $\mathrm{x}$ & $0.985^{* * *}$ & $0.826^{* * *}$ & $0.780 * * *$ & 0.610 ** & $0.641^{* * *}$ \\
\hline Microtox-15' & & & & & $\mathrm{x}$ & $0.865^{* * *}$ & $0.822 * * *$ & 0.568 ** & $0.605^{* *}$ \\
\hline Thamnotox & & & & & & $\mathrm{x}$ & 0.723 *** & $0.473 *$ & 0.506 * \\
\hline Rapidotox toxicity & & & & & & & $\mathrm{x}$ & $0.450 *$ & 0.484 * \\
\hline Ostracod-growth & & & & & & & & $\mathrm{x}$ & $0.954^{* * *}$ \\
\hline
\end{tabular}

$*, * *, * * *$ Asterisks indicate the significance of correlations: $p<0.05, p<0.01$, and $p<0.001$, respectively.

\section{Active variables at the background of principal components 1 and 2}

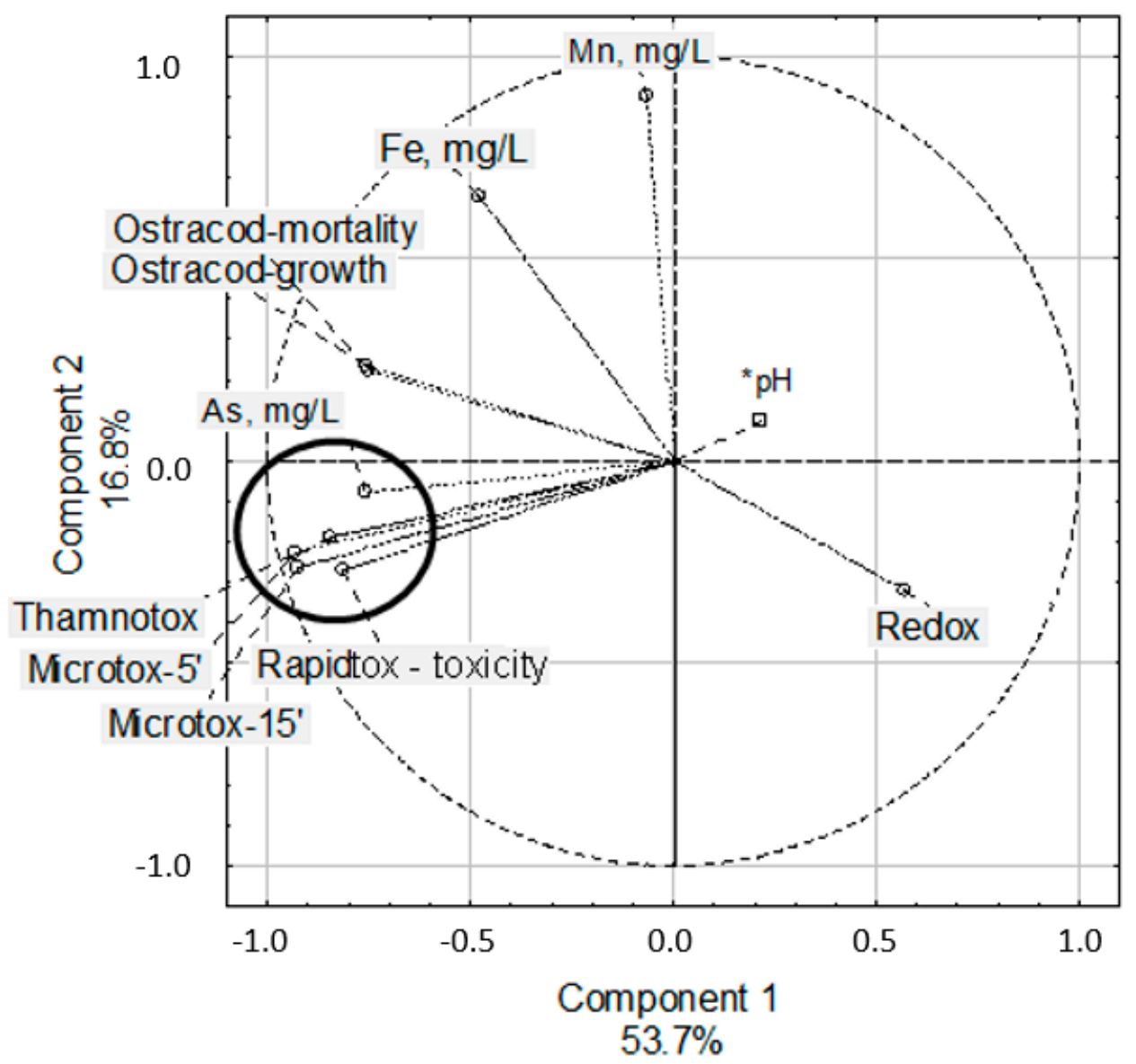

Figure 6. The results of PCA analysis. Active variables projected on 2-D plot of principal components 1 and 2.

The attention should be given to the fact that the toxicity revealed by the Ostracod tests for soil S2-both with and without the addition of forest litter-was greater than that shown for soil S1, despite much lower total As concentration in the soil S2. Moreover, soil $\mathrm{S} 2$ had acidic $\mathrm{pH}$, which normally would not promote a release of As from the solid phase. Relatively high toxicity found in the Ostracodtox test in the case of this soil, particularly under prolonged waterlogging, should be attributed to a relatively high solubility of both As, and $\mathrm{Mn}$ and Fe, the latter being higher than in the soil S2. Ostracodtox test performed in much longer time ( 6 days) than the other assays, seems to be much more sensitive to 
sub-toxic concentrations of contaminants in pore water. Moreover, similarly to the tests with springtails, it is believed to indicate a full toxicity of sediments of soils, including that caused by a "direct contact" and resulting from the ingestion of solid particles that contain potentially bioavailable species of toxic components [34,58,59].

\section{Conclusions}

All the bioassays performed in this study turned out to be good tools for identifying high concentrations of As in pore water of soils in the forested areas of former As mining industry. Tests with crustaceans indicated that-despite the low solubility of As in soilsits presence can cause a very high toxicity to soil fauna. The results of tests that were adapted from standard analysis of acute toxicity in natural water (Microtox, Rapidtox and Thamnotox) showed a very good correlation with As concentrations in soil solution. It has also been confirmed that the bioassays with crustaceans (T. platyurus, H. incongruens) are more sensitive than those with luminescent bacteria $V$. fischeri.

The input of forest litter into the soil may significantly increase its toxicity-not only in the presence of toxic As, but also in unpolluted soils. The sub-acute toxicity test based on the direct contact of Ostracod crustaceans with soil is particularly sensitive in this respect. Waterlogged conditions may cause increased release of As into the solution in polluted soils, and the addition of forest litter can accelerate this effect and radically increase the toxicity of soil pore water and the soil itself. This effect deepens over time up to 21 days.

For a comprehensive interpretation of experimental results obtained from bioassays, comparative studies should be performed with a real soil fauna, for instance with springtails and earthworms, with considering various soil properties, various conditions and speciation of arsenic in soil system.

Author Contributions: Conceptualization, K.S. and A.K.; methodology, K.S., I.G., K.G. and A.K.; software, K.S.; validation, A.K. and K.S.; formal analysis, A.D. and K.S.; investigation, K.S., I.G., D.G., K.G. and B.G.; resources, B.G.; data curation, K.S. and D.G.; writing-original draft preparation, K.S. and I.G.; writing-review and editing, A.K. and A.D.; visualization, K.S. and A.K.; supervision, A.K.; project administration, A.K. and A.D.; funding acquisition, A.K., K.S., A.D. All authors have read and agreed to the published version of the manuscript.

Funding: This research was funded by NATIONAL SCIENCE CENTRE OF POLAND, grant number 2016/21/B/ST10/02221.

Acknowledgments: We would like to express the special thanks to Bogna Kosyk for her assistance in performing laboratory analyses.

Conflicts of Interest: The authors declare no conflict of interest.

\section{References}

1. Krysiak, A.; Karczewska, A. Arsenic extractability in soils in the areas of former arsenic mining and smelting, SW Poland. Sci. Total Environ. 2007, 379, 190-200. [CrossRef]

2. Karczewska, A.; Krysiak, A.; Mokrzycka, D.; Jezierski, P.; Szopka, K. Arsenic distribution in soils of a former as mining area and processing. Pol. J. Environ. Stud. 2013, 22, 175-181.

3. Drahota, P.; Filippi, M. Secondary arsenic minerals in the environment: A review. Environ. Intern. 2009, 35, 1243-1255. [CrossRef]

4. Basu, A.; Schreiber, M.E. Arsenic release from arsenopyrite weathering: Insights from sequential extraction and microscopic studies. J. Hazard. Mater. 2013, 262, 896-904. [CrossRef] [PubMed]

5. Wenzel, W.W. Arsenic. In Heavy Metals in Soils. Trace Metals and Metalloids in Soils and Their Bioavailability, 3rd ed.; Alloway, B.J., Ed.; Springer: Berlin, Germany, 2013; pp. 241-282.

6. Campbell, K.M.; Nordstrom, D.K. Arsenic speciation and sorption in natural environments. Rev. Miner. Geochem. 2014, 79, 185-216. [CrossRef]

7. Bauer, M.; Blodau, C. Mobilization of arsenic by dissolved organic matter from iron oxides, soils and sediments. Sci. Total Environ. 2006, 354, 179-190. [CrossRef] [PubMed]

8. Bolan, N.S.; Mahimairaja, S.; Kunhikrishnan, A.; Choppala, G. Phosphorus-arsenic interactions in variable-charge soils in relation to arsenic mobility and bioavailability. Sci. Total Environ. 2013, 463, 1154-1162. [CrossRef] [PubMed]

9. Arco-Lázaro, E.; Agudo, I.; Clemente, R.; Bernal, M. Arsenic (V) adsorption-desorption in agricultural and mine soils: Effects of organic matter addition and phosphate competition. Environ. Pollut. 2016, 216, 71-79. [CrossRef] [PubMed] 
10. Karczewska, A.; Lewińska, K.; Siepak, M.; Gałka, B.; Dradrach, A.; Szopka, K. Transformation of beech forest litter as a factor that triggers arsenic solubility in soils developed on historical mine dumps. J. Soils Sed. 2018, 18, 2749-2758. [CrossRef]

11. Lewińska, K.; Karczewska, A.; Siepak, M.; Szopka, K.; Gałka, B.; Iqbal, M. Effects of waterlogging on the solubility of antimony and arsenic in variously treated shooting range soils. Appl. Geochem. 2019, 105, 7-16. [CrossRef]

12. Dradrach, A.; Szopka, K.; Karczewska, A. Ecotoxicity of soil pore water on historical arsenic mine dumps the effects of forest litter. Ecotoxicol. Environ. Saf. 2019, 181, 202-213. [CrossRef]

13. Violante, A.; Cozzolino, V.; Perelomov, L.; Caporale, A.G.; Pigna, M. Mobility and bioavailability of heavy metals and metalloids in soil environments. J. Soil Sci. Plant Nutr. 2010, 10, 268-292. [CrossRef]

14. Huang, J.H. Impact of microorganisms on arsenic biogeochemistry: A review. Water Air Soil Pollut. 2014, 225, 1-25. [CrossRef]

15. Suda, A.; Makino, T. Functional effects of manganese and iron oxides on the dynamics of trace elements in soils with a special focus on arsenic and cadmium: A review. Geoderma 2016, 270, 68-75. [CrossRef]

16. Han, Y.S.; Park, J.H.; Kim, S.J.; Jeong, H.Y.; Ahn, J.S. Redox transformation of soil minerals and arsenic in arsenic-contaminated soil under cycling redox conditions. J. Hazard. Mater. 2019, 378, 120745. [CrossRef]

17. Dixit, S.; Hering, J.G. Comparison of arsenic (V) and arsenic (III) sorption onto iron oxide minerals: Implications for arsenic mobility. Environ. Sci. Technol. 2003, 37, 4182-4189. [CrossRef]

18. Yamamura, S.; Amachi, S. Microbiology of inorganic arsenic: From metabolism to bioremediation. J. Biosci. Bioeng. 2014, 118, 1-9. [CrossRef]

19. Grafe, M.; Eick, M.J.; Grossl, P.R. Adsorption of arsenate (V) and arsenite (III) on goethite in the presence and absence of dissolved organic carbon. Soil Sci. Soc. Am. J. 2001, 65, 1680-1687. [CrossRef]

20. Zhu, J.; Pigna, M.; Cozzolino, V.; Caporale, A.G.; Violante, A. Sorption of arsenite and arsenate on ferrihydrite: Effect of organic and inorganic ligands. J. Hazard. Mater. 2011, 189, 564-571. [CrossRef]

21. Karczewska, A.; Lewińska, K.; Gałka, B. Arsenic extractability and uptake by velvetgrass Holcus lanatus and ryegrass Lolium perenne in variously treated soils polluted by tailing spills. J. Hazard. Mater. 2013, 262, 1014-1021. [CrossRef] [PubMed]

22. Moreno-Jiménez, E.; Clemente, R.; Mestrot, A.; Meharg, A.A. Arsenic and seleniummobilisation fromorganic matter treatedmine spoil with and without inorganic fertilization. Environ. Pollut. 2013, 173, 238-244. [CrossRef]

23. Qiao, W.; Guo, H.; He, C.; Shi, Q.; Xiu, W.; Zhao, B. Molecular evidence of arsenic mobility linked to biodegradable organic matter. Environ. Sci. Technol. 2020, 54, 7280-7290. [CrossRef]

24. Rocco, C.; Seshadri, B.; Adamo, P.; Bolan, N.S.; Mbene, K.; Naidu, R. Impact of waste-derived organic and inorganic amendments on the mobility and bioavailability of arsenic and cadmium in alkaline and acid soils. Environ. Sci. Pollut. 2018, 25, 896-905. [CrossRef] [PubMed]

25. Labaz, B.; Galka, B.; Bogacz, A.; Waroszewski, J.; Kabala, C. Factors influencing humus forms and forest litter properties in the mid-mountains under temperate climate of southwestern Poland. Geoderma 2014, 230, 265-273. [CrossRef]

26. Bradford, M.A.; Berg, B.; Maynard, D.S.; Wieder, W.R.; Wood, S.A. Understanding the dominant controls on litter decomposition. J. Ecol. 2016, 104, 229-238. [CrossRef]

27. Kawałko, D.; Halarewicz, A.; Kaszubkiewicz, J.; Jezierski, P. Decomposition rate of the litter fall in the course of riparian habitat changes. Sylwan 2017, 161, 565-572.

28. Alves, P.R.L.; Cardoso, E.J.B.N. Overview of the standard methods for soil ecotoxicology testing. Invertebr.-Exp. Models Tox. Screen. 2016, 35-56. [CrossRef]

29. Paton, G.I.; Killham, K.; Weitz, H.J.; Semple, K.T. Biological tools for the assessment of contaminated land: Applied soil ecotoxicology. Soil Use Manag. 2005, 21, 487-499. [CrossRef]

30. Wieczerzak, M.; Namieśnik, J.; Kudłak, B. Bioassays as one of the Green Chemistry tools for assessing environmental quality: A review. Environ. Int. 2016, 94, 341-361. [CrossRef]

31. Kokkali, V.; van Delft, W. Overview of commercially available bioassays for assessing chemical toxicity in aqueous samples. TrAC Trends Anal. Chem. 2014, 61, 133-155. [CrossRef]

32. Karczewska, A.; Kabała, C. Environmental risk assessment as a new basis for evaluation of soil contamination in Polish law. Soil Sci. Ann. 2017, 68, 67-80. [CrossRef]

33. Häder, D.P. Historical development of bioassays. In Bioassays; Elsevier: Amsterdam, The Netherlands, 2018 ; pp. 41-49.

34. Kudłak, B.; Wolska, L.; Namieśnik, J. Determination of EC 50 toxicity data of selected heavy metals toward Heterocypris incongruens and their comparison to "direct-contact" and microbiotests. Environ. Monit. Assess. 2011, 174, 509-516. [CrossRef]

35. Palma, P.; Ledo, L.; Alvarenga, P. Ecotoxicological endpoints, are they useful tools to support ecological status assessment in strongly modified water bodies? Sci. Total Environ. 2016, 541, 119-129. [CrossRef]

36. Tan, K. Soil Sampling, Preparation, and Analysis, 2nd ed.; CRC Press, Taylor \& Francis Group: Boca Raton, FL, USA, 2005.

37. Gregorich, E.G.; Beare, M.H.; Stoklas, U.; St-Georges, P. Biodegradability of soluble organic matter in maize-cropped soils. Geoderma 2003, 113, 237-252. [CrossRef]

38. U.S. EPA Method 3051A: Microwave Assisted Acid Digestion of Sediments, Sludges, and Oils. 2007. Available online: https: //www.epa.gov/sites/production/files/2015-12/documents/3051a.pdf (accessed on 15 March 2021).

39. ISO 19730: 2008. Soil Quality_Extraction of Trace Elements from Soil Using Ammonium Nitrate Solution; International Organization for Standardization: Geneva, Switzerland, 2008. 
40. ISO 11348-3:2007/AMD 1:2018. Water Quality_Determination of the Inhibitory Effect of Water Samples on the Light Emission of Vibrio fischeri (Luminescent Bacteria Test)_Part 3: Method Using Freeze-Dried Bacteria_Amendment 1; International Organization for Standardization: Geneva, Switzerland, 2018.

41. Doherty, F. A review of the Microtox ${ }^{\circledR}$ toxicity test system for assessing the toxicity of sediments and soils. Water Qual. Res. J. 2001, 36, 475-518. [CrossRef]

42. Abbas, M.; Adil, M.; Ehtisham-ul-Haque, S.; Munir, B.; Yameen, M.; Gha_ar, A.; Iqbal, M. Vibrio fischeri bioluminescence inhibition assay for ecotoxicity assessment: A review. Sci. Total Environ. 2018, 626, 1295-1309. [CrossRef]

43. Urbanczyk, H.; Ast, J.C.; Higgins, M.J.; Carson, J.; Dunlap, P.V. Reclassification of Vibrio fischeri, Vibrio logei, Vibrio salmonicida and Vibrio wodanis as Aliivibrio fischeri gen. nov., comb. nov., Aliivibrio logei comb. nov., Aliivibrio salmonicida comb. nov. and Aliivibrio wodanis comb. nov. Int. J. Syst. Evol. Microbiol. 2007, 57, 2823-2829. [CrossRef]

44. SDI, 1992; Microtox Manual. Microbics Corporation: Carlsbad, CA, USA, 1992.

45. Törökné, A.; Vasdinnyei, R.; Asztalos, B.M. A rapid microbiotest for the detection of cyanobacterial toxins. Environ. Toxicol. Intern. 2007, 22, 64-68. [CrossRef]

46. Dries, J.; Daens, D.; Geuens, L.; Blust, R. Evaluation of acute ecotoxicity removal from industrial wastewater using a battery of rapid bioassays. Water Sci. Technol. 2014, 70, 2056-2061. [CrossRef]

47. Vidal, T.; Santos, J.I.; Queirós, L.; Ré, A.; Abrantes, N.; Gonçalves, F.J.M.; Pereira, J.L. Environmental benchmarks based on ecotoxicological assessment with planktonic species might not adequately protect benthic assemblages in lotic systems. Sci. Total Environ. 2019, 668, 1289-1297. [CrossRef] [PubMed]

48. Sieroslawska, A. Evaluation of the Sensitivity of Organisms Used in Commercially Available Toxkits to Selected Cyanotoxins. Pol. J. Environ. Stud. 2013, 22, 1817-1823.

49. ISO 14380:2011 Water Quality—Determination of the Acute Toxicity to Thamnocephalus Platyurus (Crustacea, Anostraca). 2011. Available online: https:/ / standards.iteh.ai/catalog/standards/sist/b09176b1-9c2e-4fce-8c97-6aa92b1fd53c/sist-iso-14380-2012 (accessed on 15 March 2021).

50. Hiki, K.; Tobino, T.; Nakajima, F.; Tsukahara, K. Duration of life-cycle toxicity tests with the ostracod Heterocypris incongruens. Environ. Toxicol. Chem. 2017, 36, 3443-3449. [CrossRef]

51. Płaza, G.A.; Nałęcz-Jawecki, G.; Pinyakong, O.; Illmer, P.; Margesin, R. Ecotoxicological and microbiological characterization of soils from heavy-metal-and hydrocarbon-contaminated sites. Environ. Monit. Assess. 2010, 163, 477-488. [CrossRef]

52. ISO 14371:2012 Water Quality-Determination of Fresh Water Sediment Toxicity to Heterocypris incongruens (Crustacea, Ostracoda); International Organization for Standardization: Geneva, Switzerland, 2012.

53. Melnyk, A.; Kuklińska, K.; Wolska, L.; Namieśnik, J. Chemical pollution and toxicity of water samples from stream receiving leachate from controlled municipal solid waste (MSW) landfill. Environ. Res. 2014, 135, 253-261. [CrossRef]

54. Kappler, A.; Amstaetter, K.; Borch, T.; Larese-Casanova, P.; Jiang, J.; Bauer, I.; Paul, A. Arsenic redox transformation by humic substances and Fe minerals. Appl. Geochem. 2011, 26, S317. [CrossRef]

55. Anawar, H.M.; Akai, J.; Yoshioka, T.; Konohira, E.; Lee, J.Y.; Fukuhara, H.; Tari Kul Alam, M.; Garcia-Sanchez, A. Mobilization of arsenic in groundwater of Bangladesh: Evidence from an incubation study. Environ. Geochem. Health 2006, 28, 553-565. [CrossRef] [PubMed]

56. Burton, E.D.; Johnston, S.G.; Kocar, B.D. Arsenic mobility during flooding of contaminated soil: The effect of microbial sulfate reduction. Environ. Sci. Technol. 2014, 48, 13660-13667. [CrossRef] [PubMed]

57. Langner, P.; Mikutta, C.; Kretzschmar, R. Arsenic sequestration by organic sulphur in peat. Nat. Geosci. 2012, 5, 66-73. [CrossRef]

58. Oleszczuk, P. Heterocypris incongruens as a tool to estimate sewage sludge toxicity. Environ. Toxicol. Chem. 2008, 27, 864-872. [CrossRef]

59. Lin, X.; Sun, Z.; Zhao, L.; Ma, J.; Li, X.; He, F.; Hou, H. The toxicity of exogenous arsenic to soil-dwelling springtail Folsomia candida in relation to soil properties and aging time. Ecotox. Environ. Saf. 2019, 171, 530-538. [CrossRef] 